\title{
A CONTRIBUTION TO OUR KNOWLEDGE OF THE LIFE HISTORY OF ARENICOLA MARINA L.
}

\author{
By G. E. Newell, B.Sc., Ph.D.
}

From the Department of Zoology, Queen Mary College, University of London.

(Text-figs. I-I2)

\begin{tabular}{|c|c|c|c|c|c|c|c|c|c|}
\hline & & $\mathrm{CON}^{\prime}$ & $\mathrm{T}$ & TS & & & & & \\
\hline Introduction & & • & . & . & . & . & & & \\
\hline Acknowledg & ments & & • & • & . & & & & \\
\hline The Breedin & Season & . & & . & & & & & \\
\hline Maturation a & ad Structu & re of th & & rerm & Cells & 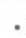 & & & \\
\hline Discharge of & the Germ & Cells . & . & . & . & . & & & \\
\hline Sex Ratio & & . & . & . & . & . & & & \\
\hline Artificial Ins & mination & & & . & . & . & & & \\
\hline Early Develo & pment of $t$ & he Egg & & . & . & & & & \\
\hline Size Groups & and Grow & h Rates & & . & . & . & & & \\
\hline Migrations & . & .. & . & . & . & . & & & \\
\hline nmary & . & . & . & . & . & . & & & \\
\hline eferences & . & . & . & . & . & - & . & & \\
\hline
\end{tabular}

\section{INTRODUCTION}

A survey of the literature reveals the rather surprising fact that the breeding habits and spawning of the common British lugworm, Arenicola marina L., which is such a frequent and conspicuous member of the polychaete fauna of our intertidal zone, are by no means fully known.

Most of the available accounts deal with lugworms on various continental shores and there are also good descriptions of spawning and early development of the Pacific lugworm, A. cristata. There seem to be no recent references to the breeding of lugworms off British coastlines. Such accounts as exist are by no means in complete agreement, even on such important points as the time of the breeding season, its duration, or on the possibility of the seasonal occurrence of a pelagic spawning phase, whilst descriptions of the early development are almost completely lacking.

Thamdrup (1935), one of the more recent workers on the breeding season of European lugworms, was led, as a result of his own observations on the mud-dwelling fauna of Skalling and from results of previous authors, to put forward a 'working hypothesis', as he terms it, in order to link up the known facts. Thamdrup believed that the worms spawn in a period restricted to a few days and probably related to definite phases of the moon, in the late summer. The resulting larvae, he thought, live pelagically throughout the winter (a suggestion due to Blegvad, 1923) and then take to the bottom some time in April and June. Here they grow through the summer and winter to a size 
which then lies within the adult size-group range. The young worms may spawn during the second summer after they have hatched from the egg. These conclusions of Thamdrup are to a large extent based on those of Blegvad (I923) and of Pirlot (1933). Pirlot studied the lugworms of the Belgian coast, particularly at Blankenburghe. Here he noted that in September and the early part of October all the worms except the very small ones had gametes filling the coelom, but that after I5 October and throughout the winter no gametes were to be found in the body cavity. Spawning was restricted to a 2-day crisis at either the full or new moon, and in I928 was on the I3-I4 October, in I932 on I4-I5 October and in I933 on 6-7 October. The weather had, apparently, no effect on spawning, which is probably governed by a lunar effect acting indirectly through the tides. Pirlot states that both sperms and eggs remain immature until they pass out of the body via the nephridia, and he was unable to obtain a successful artificial insemination from coelomic gametes. For this reason he remained unacquainted with the early larva. He found, however, larvae with one pair of chaetigerous segments in the sand about I4 days after the spawning crisis. In fact, with the doubtful exception of Child (1898), who merely describes fertilization and maturation (but no later stages) of the eggs of the American A. marina, Pirlot's failure with artificial means is typical of all other results. Naturally fertilized eggs have been recorded on two occasions. The first is that of Blegvad (I923), who was fortunate enough to find some eggs laid by worms in the aquarium at the Nyborg Biological Station. These were deposited loosely on the sand and conformed closely to the description given by Ashworth (I904). They were laid on 6 August 1923 and hatched into trochophores 4 days later. These and larvae with three chaetigerous segments were briefly described and figured. After reaching this stage of development the brood of larvae died. However, in successive Septembers Blegvad obtained larvae with five chaetigerous segments, but no stages between this and the 'post-larval' stages of Benham (I893) were seen. Post-larval stages occur in numbers in the early spring from April to June, and Blegvad believed that the pelagic larval stage must extend over the whole winter.

The second record of early larvae is that quoted by Thorson (1946), who mentions that Erik Smidt (unpublished) found newly hatched larvae crawling among the sand grains of the tidal zone at Esbjerg, but these are not described in Thorson's paper. Pelagic larvae were never found by Thorson, despite very extensive plankton hauls, and he believes that such a stage is omitted from the life cycle, the larva from the beginning being a bottom-dweller. The breeding season of lugworms in Danish waters takes place in the autumn, as is shown by the presence of coelomic gametes in August onwards for some time and by their absence in the spring. Post-larval stages as described by Benham were also not found, and it is suggested that when they occur they may be bottom stages that have been stirred up accidentally, or else they are abnormalities 
due to larvae metamorphosing in mid-water. The fact that young bottomdwelling, metamorphosed worms are first met with in the summer may be explained by assuming that the young larvae settle in the autumn soon after hatching, and then stagnate until the rise in temperature of the following spring, when growth is resumed.

It will be seen from these summaries that whilst the accounts of Blegvad and Pirlot are substantially in agreement they differ in many important respects from that of Thorson and, as will be mentioned below, all three differ from those of British workers.

The possible occurrence of a pelagic stage or swarming of breeding adults has been discussed by several workers, notably by Fage \& Legendre (1927), who give a useful review of what was known of the breeding habits of lugworms up to that date. It appears that the evidence for a swimming phase rests on a few but perfectly definite observations, some of which are by British observers, and on reports by fishermen. Meek \& Storrow (1924), for example, noticed lugworms swimming at the surface of the sea in Northumberland for 2 days, $2 \mathrm{I}$ and $22 \mathrm{March}$, at the time of the full moon. The worms were enclosed in a gelatinous capsule which, it is suggested, may act as a float. All the worms were spent as if breeding had just taken place. This conclusion is, however, open to criticism, for it may well have happened that the gametes had not yet begun to develop for that season. In fact, Storrow himself (1925) noticed Arenicola sperms in the sand on 23-24 September 1924, which suggests an autumn breeding season. Fage \& Legendre and also Pirlot (who was unable to find pelagic adults) take the view that if a pelagic phase does occur it is not directly related to the emission of the gametes.

From these various sources it would seem fair to summarize our knowledge of the breeding habits of lugworms on the shores of Europe as follows:

(i) Breeding is restricted to a period of a few days in the autumn and is probably related to spring tides. (ii) Gametes pass out through the nephridia and are fertilized in the sea. Before discharge, coelomic gametes are not fully mature. (iii) It is uncertain if the larva is a free-swimming trochophore with a lengthy pelagic life extending until the spring following hatching, or if the pelagic phase is omitted or curtailed. Recent evidence (Thorson) suggests that the latter alternative is more likely. (iv) There are almost certainly occasions on which the worms forsake their burrows and swim actively in the surface waters, but this burst of activity may, or may not, be related to spawning. The evidence here is very fragmentary. (v) All the accounts so far cited agree that the eggs are not enclosed in any sort of gelatinous capsule after they have been laid. This is an important point of difference between $A$. marina and certain other species, e.g. A. cristata, a Pacific lugworm common in Japan and America. The eggs of $A$. cristata and their capsules have recently been redescribed by Okada (I94I), who also showed that spawning takes place at 4-day intervals from July to September during which period eggs and sperms 
are discharged synchronously throughout the whole habitat. Fertilization is aided by the close proximity of male and female burrows which connect one with the other so that the eggs are fertilized in them.

With regard to the breeding of lugworms in British waters it appears from the fragmentary and conflicting accounts that very little is known with certainty. Thus, Cunningham \& Ramage (I888) state that in the Firth of Forth the gametes are shed in August and September. Kyle (1896), on the other hand, believed that the breeding season extends from January to September though with a cessation during April, May and early June. Gamble \& Ashworth (I900) stated that the ordinary littoral forms of $A$. marina of the Lancashire coasts are not mature in the spring, but breed throughout the summer when the deeper water variety has ceased to do so. In a later publication (I904) Ashworth, who again worked at stations on the Lancashire coast and also on the Firth of Forth, states that two varieties of $A$. marina are to be found in these districts. One, smaller and abundant in the littoral zone, appears to be the form most usually met with in the British Isles and on the Continent. The other, large and having slight morphological differences from the littoral form, is restricted to the laminarian zone. Using as his criterion the presence of ripe eggs or sperms in the coelom, Ashworth concluded that the smaller, littoral variety breeds in the spring, usually from the end of February onwards for about a month or more, but he found specimens containing ripe 'ova' up to the end of April or even later. Unfortunately, Ashworth does not give any exact description of what he means by 'ripe gametes' and, as will be mentioned later, a superficial examination of the stage of maturity of the coelomic gametes gives only a rather vague indication of the time of the breeding season. The larger laminarian variety of lugworm breeds in March and onwards, but Ashworth is inclined to believe that both varieties may have a second spawning season in the late summer. This double-breeding season is certainly true for A. ecaudata, as mentioned by Hentschel (1930). The actual release of the gametes into the sea was not observed by Ashworth, but he believed that they pass out through the last five pairs of nephridia. He, then, like later workers, disagrees with Bohn (I903) who thought that the germ cells passed out through temporary perforations in the body wall. Full descriptions of the eggs and sperms are given in Ashworth's monograph and also an account of cleavage and early larva of $A$. claparedii, but it is stated that nothing is known of stages intermediate between the egg and the post-larval stages of Benham for A. marina. For British lugworms his statement would seem to be substantially correct up to the present day. Reference must, however, be made to a paper by Williamson (I9I6). His observations were made on the worms of the Bay of Nigg, but the species, although probably $A$. marina, was not determined in all instances. Williamson noted that ripe sperms were discharged on 2 October from worms kept in an aquarium and also believed that egg masses discharged at intervals from May to June also belonged to Arenicola. These 
egg masses were gelatinous, green in colour and contained numerous green eggs. A few days later they contained greenish embryos with two eye spots. They closely resembled egg masses found on the beaches where they were anchored by strands to the substratum or to sea weeds. Each egg mass was apparently composed of a ball of fibres loosely invested in a thin outer skin which it was believed was the cast cuticle of the female worms. In view of the wide differences between this description and those of other authors, and because other polychaetes such as Capitella and Polydora were also present in Williamson's aquarium, some doubt must attach to the view that the greenish egg masses were really spawned by Arenicola.

The embryology of lugworms has been fully dealt with up to the formation of the young larva by Child (I900) and by Okada (I94I). Both of these authors worked on A. cristata. Ashworth (1904) gives a somewhat briefer description of the development of $A$. claparedii. All the descriptions are substantially in agreement, and the cell lineage seems to follow the usual polychaete plan. Descriptions of the free-living larvae of $A$. cristata are given by Lillie (I905) which agree with those of earlier workers, e.g. Child (I897).

This review serves to show that whilst a good deal is known of the breeding and embryology of foreign lugworms of various species, yet a re-examination of the life histories of British lugworms is needed to fill in gaps in our knowledge. Points which seem of particular interest are the duration and season of the year at which breeding takes place; the correlation between spawning and the tides; the method of egg-laying and fertilization; the nature and duration of larval life and a description of later stages.

This paper deals exclusively with the lugworms of the Whitstable Flats and the results may well not apply to other districts.

\section{ACKNOWLEDGEMENTS}

It is with pleasure that I tender my thanks to Mr G.P. Wells for his suggestion that I should investigate the breeding habits of the common lugworm. Not only has he given me much help and encouragement but has also very kindly read through the manuscript. Mr D. P. Wilson was kind enough to give me considerable help with the literature. The work has proved a good deal more arduous than I expected and the records I have kept could not have been so complete were it not for the very considerable help I have received from my small children who throughout the severe winter of I946-47 helped me collect my specimens. Mr Cullen of Queen Mary College took the photographs of the developing eggs and to him I am extremely grateful.

\section{The Breeding Season}

As already mentioned, there is considerable disagreement in the literature as to the time and duration of the breeding season of $A$. marina, some sources stating that it occurs in the spring, others in the autumn. All accounts dealing 
with British lugworms, with the possible exception of Meek \& Storrow (I924), indicate a protracted period in contrast to a concerted spawning, or crisis, as described by some continental workers for the same species. Over a period of many years it has been noticed that the lugworms of the Whitstable Flats have their body cavities full of germ cells throughout the late summer and early autumn and that by the end of October all the worms are 'spent'. This clearly points to a breeding season in early autumn. A further point noticed in a purely qualitative way is that the worms are very much scarcer in the

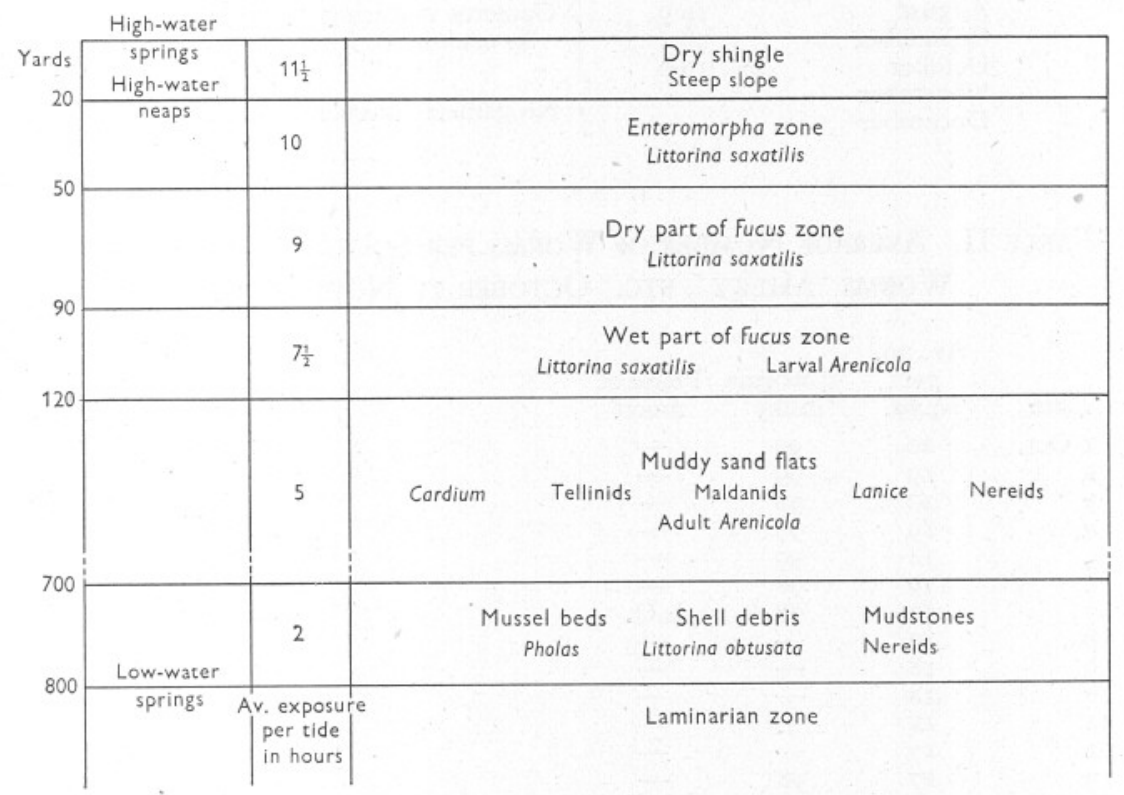

Fig. I. Diagram to show the approximate zonation and some of the commoner animals of the intertidal zones.

winter than in the summer and the impression was gained that the drop in numbers occurred rather suddenly at about the middle or end of October. If this is, in fact, true then it indicates a mortality among the spawning adults or else a migration related to spawning. It seemed that a record of the density of the worm population over a whole year, in conjunction with observations on the state of sexual maturity, would throw a good deal of light on both these points. Accordingly, with a few exceptions due to adverse weather or tides, worms were dug at weekly intervals, or even more frequently, throughout the period November 1946 to November 1947. Each sample was collected from the same general area of the Flats about 50 yards seaward of the pebble and Fucus zone (Fig. I). Each sample was usually in excess of forty worms and sampling was carried out in each instance by digging up areas measuring $6 \mathrm{ft} . \times$ I ft. 6 in., giving areas of I sq. yd., so that the density of the worm 
Table I. Average Number of Worms Per Square Yard, NOVEMber I946 To NOVEMBer I947

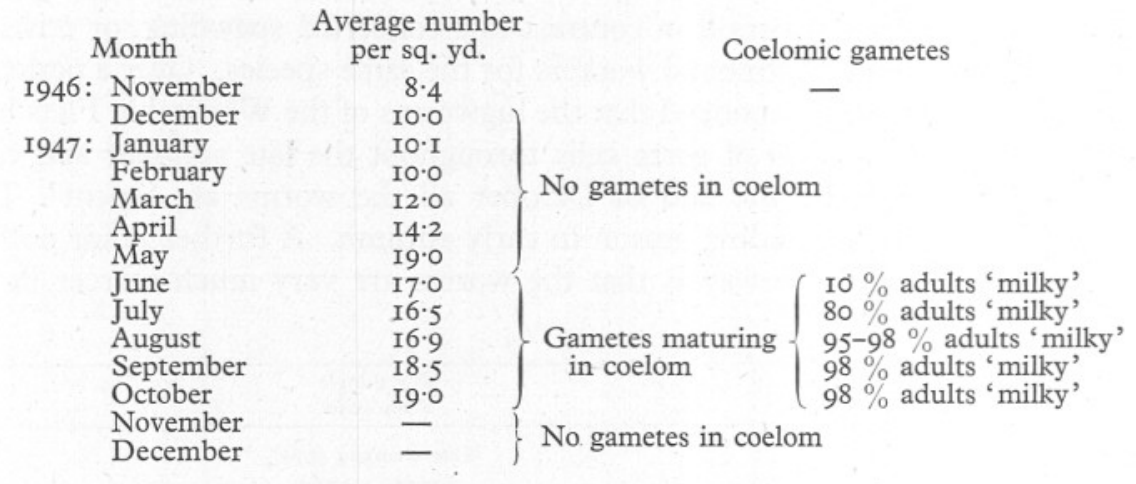

Table II. Average Number of Worms per Square Yard, Percentage Worms 'MILKy', ETC. OCTOBER TO NOVEMBER I947

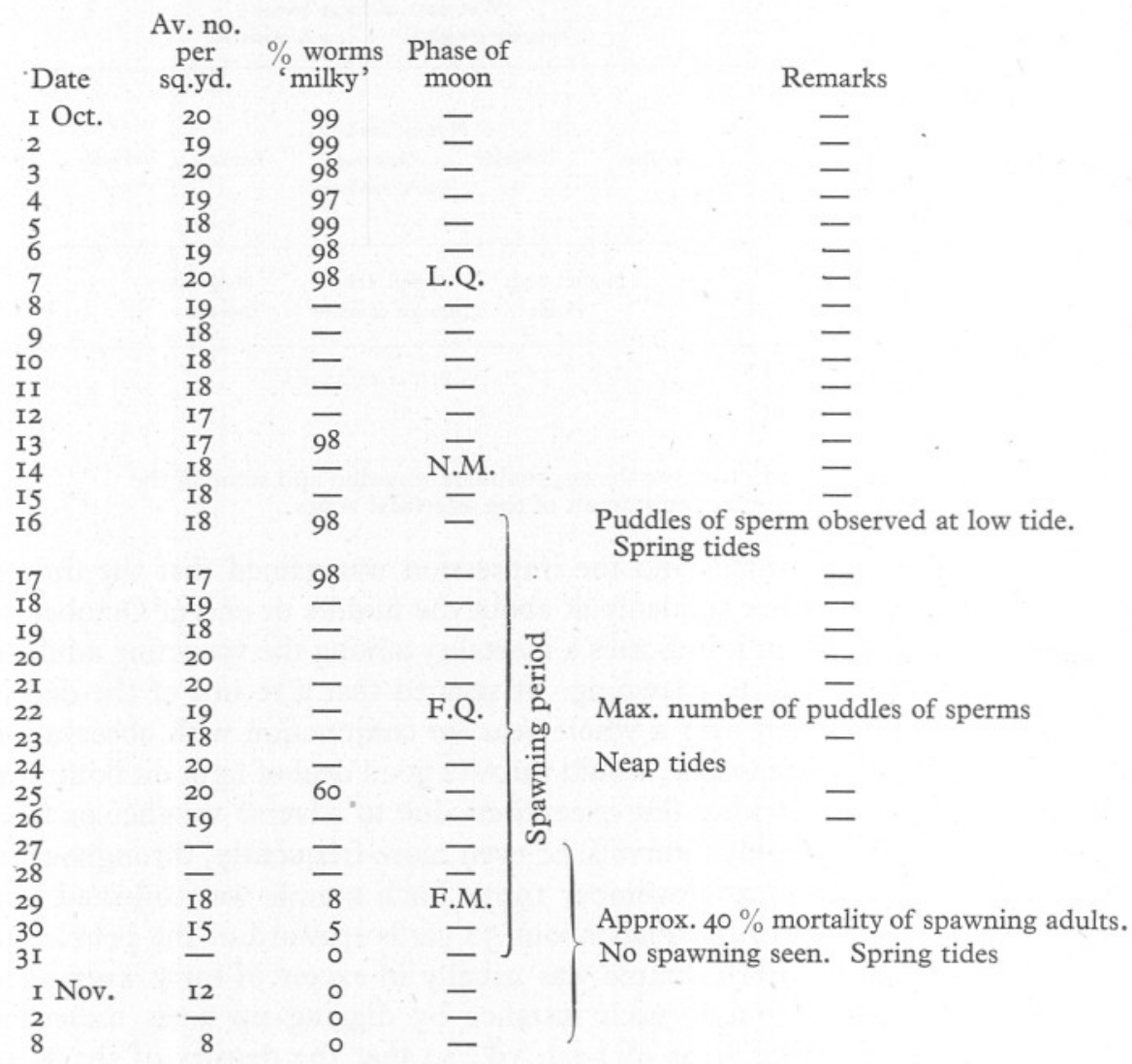


population could easily be expressed in numbers per square yard. This rather tedious method of sampling was found to be essential, since counting the number of casts per square yard is a most unreliable index of the number of worms, varying as it does with, among other conditions, the state of the tide. For most of the year there was little variation in the numbers of worms per square yard from week to week, and for simplicity the results have been consolidated and given as monthly results. For September and October, however, more frequent results are given. The results are given, together with remarks on the state of sexual maturity and phases of the moon, in Tables I and II and Figs. 2 and 3.

\section{Discussion of Results}

It will be noticed from Table I and Fig. 2 that the average number of worms per square yard rises throughout November and December, remains at about Io per square yard during January and February and then reaches the high figure of I9 per square yard in May. From this point onwards, until the end of October, it is fairly constant at between 17 and $2 \mathrm{I}$ per square yard. There is a very marked sudden decrease in numbers on or about 3I October.

The soil from which the worms were dug is a favourite area for bait diggers and minor fluctuations in the numbers of the worms may probably be attributed to their activities. The digging of lugworms for bait, cannot, however, account for any substantial decreases in the worm population, for more bait is dug throughout August and early September than at any other period of the year and yet the density of worms remains high. Furthermore, there is practically no bait dug in the middle of the winter when the worm population is at its lowest (November to February), and the numbers continue to increase from February to May during the later part of which period bait diggers resume their activities. It can be assumed, therefore, that the density of the worm population is virtually unaltered by the interference of man, and some other explanation must be sought for any striking variation in the number of worms per square yard of the soil.

An observation made in October 1946 gave a clue to the cause of the sparcity of worms in the late autumn and winter of that year, for on 26 and 27 October, on which there were neap tides, large numbers of spent worms were found cast up dead on the shore. Previous to these dates worms were plentiful, but afterwards were scarce. Unfortunately, quantitative observations had not then begun, so that no figures can be given for this period. Before the end of September 1946 the overwhelming majority of the worms were of a milky appearance owing to germ cells packing their body cavities, but of the worms remaining in the Flats after this date few only were milky, although about $75 \%$ retained a few germ cells until the end of October. By the beginning of November all were completely spent. 


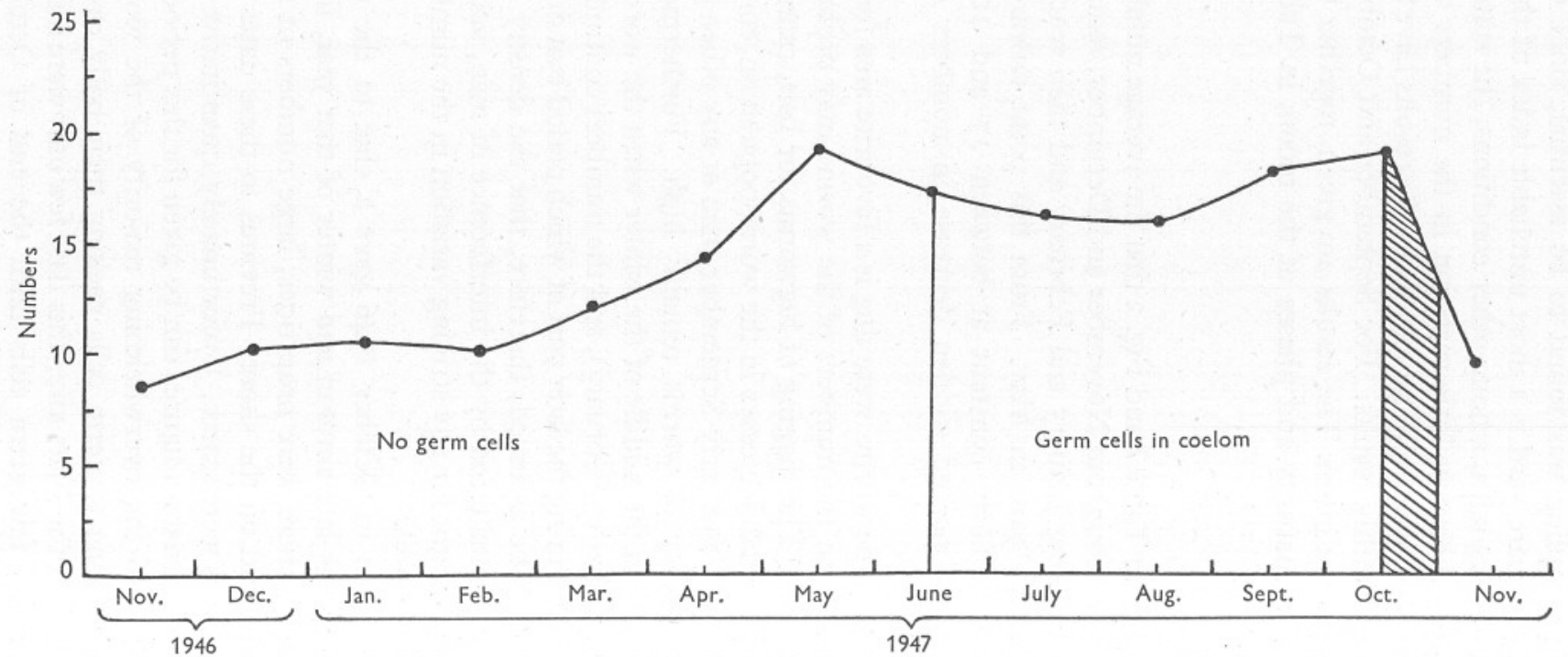

Fig. 2. Monthly variation in numbers of worms per square yard of soil dug. Shaded portion indicates spawning period. 
The upshot of these preliminary observations is that the breeding season of the lugworms of the Whitstable Flats is during a period in the autumn which agrees with statements of Blegvad (I923), Pirlot (I933), Thamdrup (I935) and Thorson (I946), whereas Kyle (I896), Ashworth (I904) and others believed the breeding season to extend through the spring and early summer. The drop in numbers noted would seem in some way to be related to spawning.

As has been seen, the general conclusions are borne out and amplified by the records kept during the period November I946 to November I947. From Table I it will be seen that germ cells in any quantity first make their appearance in the coelom in June when about Io \% of the worms appear milky. From June to the middle of October the germ cells multiply and mature, and from August onwards, until the end of October, $98 \%$ or more of the worms are 'milky'. After 3 I October all the worms are spent, although it is true that in

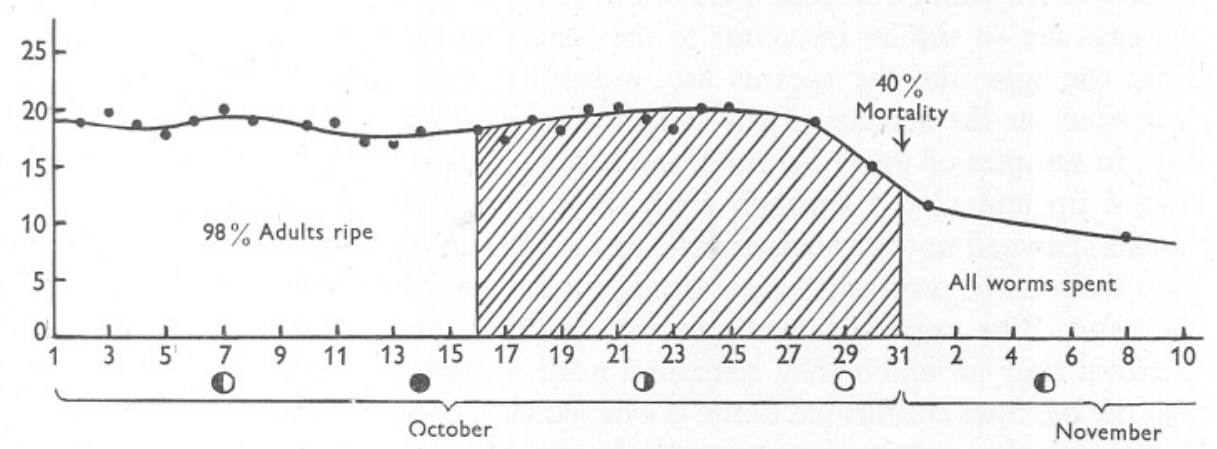

Fig. 3. Average numbers of worms per square yard of soil dug in October and November I 947 Shaded portion indicates spawning period.

about $5 \%$ of the worms a few ripe eggs and sperms could be detected, but then only in specimens dissected under a binocular microscope. They are so few in number that they can play no significant part in the main spawning process. Tables I and II clearly indicate that spawning ends on, or near to, 3I October, but they give no exact information as to when it begins. Fortunately, other evidence is available. On I6 October and onwards, until 3I October, small puddles of white fluid were noticed on the wet sand of the Flats. These proved to consist of lugworm seminal fluid containing active sperms. None was seen before dead low tide and it was later observed that the discharge of seminal fluid takes place all over the area within about half an hour. On several occasions sperms were seen being pumped out of the exit from the tail shafts of the worm burrows. Observations over the spawning period showed that spawning, as indicated by the number of sperm puddles, began slowly, reached a maximum intensity on 25 and 26 October and then decreased to finish on 3 I October. Examination of the worms at intervals also suggests very strongly that each worm can spawn several times in the fortnight, 
for there is an obvious decrease in the number of germ cells in the body cavity, although this is difficult to assess quantitatively. Not all the worms, however, become exhausted of germ cells at the same time, as is shown in Table II. Here also is indicated the relation of spawning to the phases of the moon and to spring and neap tides. It will be seen that spawning begins and ends on a spring tide, but is most intense at the intervening neap tides. The dates, but not the tidal relations, are similar to those noted by Pirlot (1933) for the lugworms of the Belgian coast. How strictly spawning is related each year to a particular moon is not known, but there is some evidence that spawning in I946 was about a fortnight earlier than in 1947 and would then have been related to the period between the spring tides following the new moon of 25 September and those following the full moon of ro October.

During the period 16-31 October close watch was kept for eggs on the surface of the sand, but none were seen. It was assumed that this was because the eggs are so similar in colour to the sand that they are virtually invisible. That the eggs like the sperms are, indeed, passed out of the burrows and deposited on the surface of the sand was proved by finding eggs on several days in samples of water in which sand from the surface of the flats had been stirred up and sieved through a plankton net. Also, on 29 October some worms spawned in the aquarium in London. When the females were spawning they frequently protruded their heads for a short time above the surface of the sand. The eggs also were passed out through the head shafts of the burrows near to which they remained until disturbed, so that it seems clear that the burrows conformed to the U-shaped variety described by Wells (1945). These females spawned on several successive days, thus confirming the conclusion reached from a study of the worms in their natural surroundings. The eggs laid in the aquarium proved to be fertilized and a brief account of their development is given below (pp. 568-70).

To sum up, it may be stated that lugworms of Whitstable, and almost certainly of neighbouring districts, spawn during 2 weeks in early autumn in the period between two spring tides. The spawning period, although sharply defined, is not a 2-day crisis as described by Pirlot, nor is it an extended one as was believed by Ashworth and others. There is only one spawning period in each year and the actual dates vary with phases of the moon. A decrease in the lugworm population takes place rather suddenly towards the end of, and immediately after, the spawning period. It is almost certainly due to death of, about $40 \%$ of the adults (probably those which have spawned) and accounts for the smaller numbers of worms present during the winter (see also pp. 5757). Some of these dead worms were found in their burrows on 8 November 1947, but in this year none was seen floating in the sea. 


\section{Maturation and Structure of the Germ Cells}

As is well known from the descriptions of Ashworth and others, the gonads are situated immediately behind the coelomic funnel of each nephridium. They remain minute in size, and for some considerable time before the breeding season immature oocytes and spermatogonia are shed from the gonads into the coelom, where they accumulate and give to the worms a milky appearance. The germ cells grow and mature in the coelom, but the oocytes, although gaining their full size, remain as primary oocytes until after they are fertilized.

It can be stated quite definitely that the lugworms of the Whitstable district for the greater part of the year, namely from the end of October until June, have no appreciable quantities of germ cells maturing in the body cavity. In I 947 the first time that germ cells were noticed was in June, when about Io \% of the adult worms had small numbers of oocytes or spermatogonia floating in the coelomic fluid. This conflicts with the findings of Ashworth (I904) for the lugworms of the Lancashire coast, for he states that 'the body cavity of large worms is filled with them almost to bursting by about the end of February' and that 'specimens containing ripe ova may be occasionally met with up to the end of April'.

Ashworth's description of the maturation of the germ cells agrees in essentials with what has been found for the Whitstable lugworms, and a redescription in detail seems, therefore, not to be called for. However, the results of the present investigation, together with any divergences from previous accounts, are summarized below. In mid-June maturing coelomic germ cells could be detected with the aid of a hand-lens in about 10 \% of the specimens dissected and it is probable that a higher percentage of worms had germ cells already liberated into the coelom, but that these escaped detection by the rough and ready methods which were employed on the shore. Previous to this date, by the same standards, no worms had any coelomic germ cells. More detailed examination revealed that the oocytes were practically spherical cells, only slightly flattened in the plane at right angles to the main egg axis. They had a largest diameter which varied from 0.07 to $0.08 \mathrm{~mm}$., whilst the nucleus had a diameter of about two-thirds that of the cell. The developing male germ cells were in the form of thick disk-like masses of spermatogonia of varying size.

By the middle of July, $80 \%$ of the adult worms were full of germ cells, even down to the end of the tail, but these seemed not to have advanced appreciably towards maturity. At the end of August $98 \%$ of the worms were 'milky'. Throughout the month of September $90 \%$ or more worms were 'milky' and coelomic germ cells were examined at fairly frequent intervals. By 8 September all the oocytes were much alike in size, being discoidal cells, usually with a circular outline but sometimes slightly oval, and having a diameter of $0.17 \mathrm{~mm}$. and a depth of $0.08 \mathrm{~mm}$. The main egg axis was at right angles to 
the plane of flattening. The cytoplasm is orange in colour and very opaque, whilst the nucleus appears in the living oocytes as a clear vesicle with a diameter of $0.06 \mathrm{~mm}$. The egg cytoplasm is full of yolk granules and has a great affinity for most stains, including haematoxylin, but permanent preparations are extremely difficult to make successfully. The vast majority of the male germ cells were spermatids, still united into flattened masses by residual cytoplasm. A few (about 10 \%), however, had metamorphosed into spermatozoa, although the tails showed no signs of motility. The heads of the spermatozoa remained

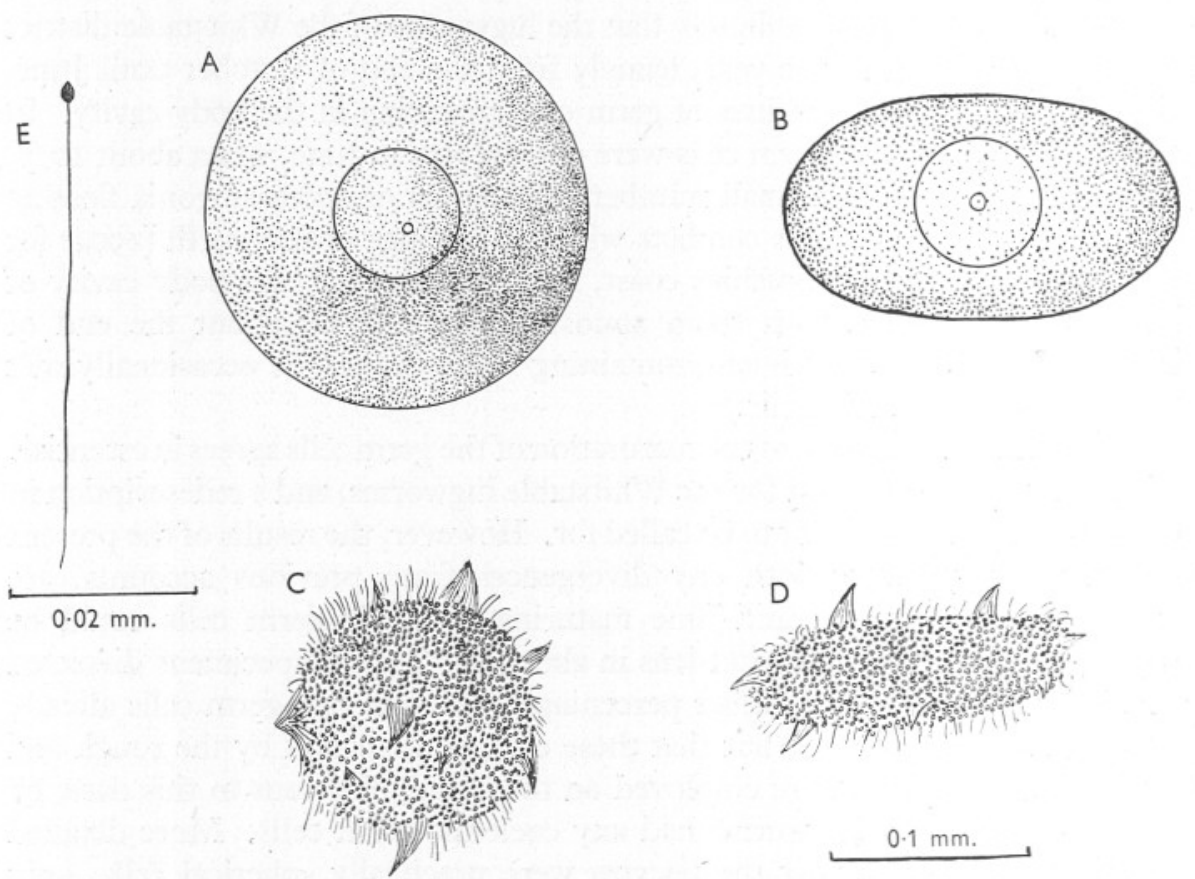

Fig. 4. A, fully grown coelomic oocyte. B, the same in side view. C, disk of mature sperms. $\mathrm{D}$, the same in side view. E, mature spermatozoon. A, B, C and D approx. $\times 210$. E approx. $\times$ I000.

attached to the central mass of cytoplasm termed by Ashworth the blastophore (Fig $4, \mathrm{C}$ and D).

By 28 September the oocytes had grown to have a diameter of $0.175 \mathrm{~mm}$. and a depth of $0.095 \mathrm{~mm}$. (Fig. 4, A and B). Little change was noticed in the male germ cells. The next detailed examination was made on 8 October, when the oocytes had attained a diameter of $0.18 \mathrm{~mm}$., but apart from this had the same appearance. In the male worms about half the sperm masses consisted of spermatozoa. On I5 October most of the sperm cells had acquired tails and some of them had limited powers of movement. In many of the sperm masses the sperm tails were united by their tips and their slow undulations 
had rather the appearance of a flagellar 'flame'. The significance of this is obscure. The oocytes by this time had attained a diameter of $0.19 \mathrm{~mm}$. It is in this stage that both male and female germ cells are discharged.

Comparison with Ashworth's diagrams and figures of the dimensions of the oocytes reveals that the oocytes of the Whitstable worms are slightly larger (0.19 $\mathrm{mm}$. as compared with $0.15 \mathrm{~mm}$.). They also differ in shape being only very slightly biconvex or even biconcave and not strongly biconvex disks. Each oocyte is surrounded by a thin but tough vitelline membrane and after being left for some time in sea water this membrane acquires a certain stickiness and the eggs adhere quite firmly to the bottom of a glass vessel. They are appreciably heavier than water and this, combined with their adhesiveness, would tend to make them remain in the sand instead of being carried away in the plankton.

The spermatozoa of Arenicola marina have been described and figured by Ashworth, and those of $A$. cristata by Okada who also gives a detailed account of gametogenesis. Whilst Ashworth reported a distinct middle piece, Okada finds that this is incorporated in the head. The accounts of the two workers differ also in the shape of the head, particularly of the acrosome. The dimensions given in each account are of the same order of size if it is assumed that Ashworth's figure of $0.04 \mathrm{~mm}$. for the length of the head should read $0.004 \mathrm{~mm}$.

Spermatozoa collected in October 1947 had a total length of $0.055 \mathrm{~mm}$., whilst the head measured $0.004 \mathrm{~mm}$. in length. The general form is shown in Fig. 4 E. Very little detail could be made out and no distinct middle piece could be detected, the tail appearing to arise directly from the head.

\section{Discharge of the Germ Cells}

As far as is known there have been no direct observations of the discharge of the germ cells from the body in A. marina, but practically all workers are agreed that the gametes pass out through the nephridia. This is certainly true for A. cristata (Okada, I94I). Ashworth noticed germ cells distending the bladders of the nephridia, but dissections of many worms during the breeding period of 1947 failed to give confirmation of this observation. Nevertheless, the germ cells are discharged without any apparent rupture of the body wall, so that it is reasonable to infer that the nephridia do function as gonoducts, but that the gametes pass out through them very rapidly.

\section{Sex Ratio}

Difficulty in finding ripe males amongst an abundance of ripe female worms suggested that there might be a differential sex ratio. Counts on 300 worms showed that this was, indeed, true, the ratio being 3.7 females to I male in August and 3.8 females to I male in September. Okada, on the other hand, found a I: I sex ratio for A. cristata, so that in this as in other respects the Japanese differs from the British lugworm. 


\section{ARTiFicial INSEMINATION}

It was found that mature spermatozoa, although still attached to the central mass of cytoplasm whilst they are in the body cavity and for a short time after they are discharged, rapidly gain their independence after a short time in sea water. Masses of coelomic sperm soon acquired motility and swam actively when transferred artificially to sea water, particularly if it was slightly hypotonic. There seems no obvious reason why sperm taken from the body cavity of ripe males and activated in sea water should not be capable of fertilizing what were apparently fully ripe oocytes from the coelom of ripe females. Yet all previous attempts at artificial insemination have come to nothing. In fact, Pirlot states definitely that the coelomic gametes are not viable until they have passed through the nephridia. Experiments carried out in October 1947 suggest that his statement is only partially true, for coelomic oocytes were induced to mature by artificial insemination with coelomic sperms to produce a fertilization membrane and undergo two cleavages. On another occasion sperm which had been shed in the natural way was collected from the sand and added to oocytes taken from a ripe female. The spermatozoa were fully active and yet the oocytes did not develop beyond the 4-cell stage. This tends to show that the inadequacy for development is a property of the oocytes rather than of the spermatozoa. Unfortunately, the converse experiment was not carried out because of failure to find unfertilized eggs naturally discharged on to the sand.

\section{EARLy DeVElopment of THE EgG}

The eggs are fertilized on or in the superficial layers of the sand, presumably shortly after the discharge of the sperm near the time of dead low water. They are then covered merely by the shallow layer of water left by the retreating tide between the sand ripples. This timing certainly must increase the chances of fertilization, preventing as it does undue dilution of the seminal fluid. Tests carried out in the laboratory, however, show that spermatozoa remain motile for at least I $8 \mathrm{hr}$. Observations on coelomic oocytes, to which had been added naturally discharged sperms, revealed that almost immediately the oocytes become surrounded by many hundreds of spermatozoa which cling to the vitelline membrane and by their activity often cause the egg to rotate. Sperm entry was not observed, but after $I_{2}^{1}-2 \mathrm{hr}$. most eggs had developed a 'fertilization membrane', and soon afterwards the first polar body was cut off. After $2-2 \frac{1}{2} \mathrm{hr}$. two polar bodies could be seen, both lying inside the egg membrane. Comparison of the diameters of unfertilized and fertilized eggs shows that the lifting clear of the fertilization membrane is due, in part at any rate, to shrinkage of the contents of the egg. With the formation of the fertilization membrane the egg loses its flattened shape and becomes practically spherical. Crossing the perivitelline space are what appear to be delicate threads of cytoplasm. 

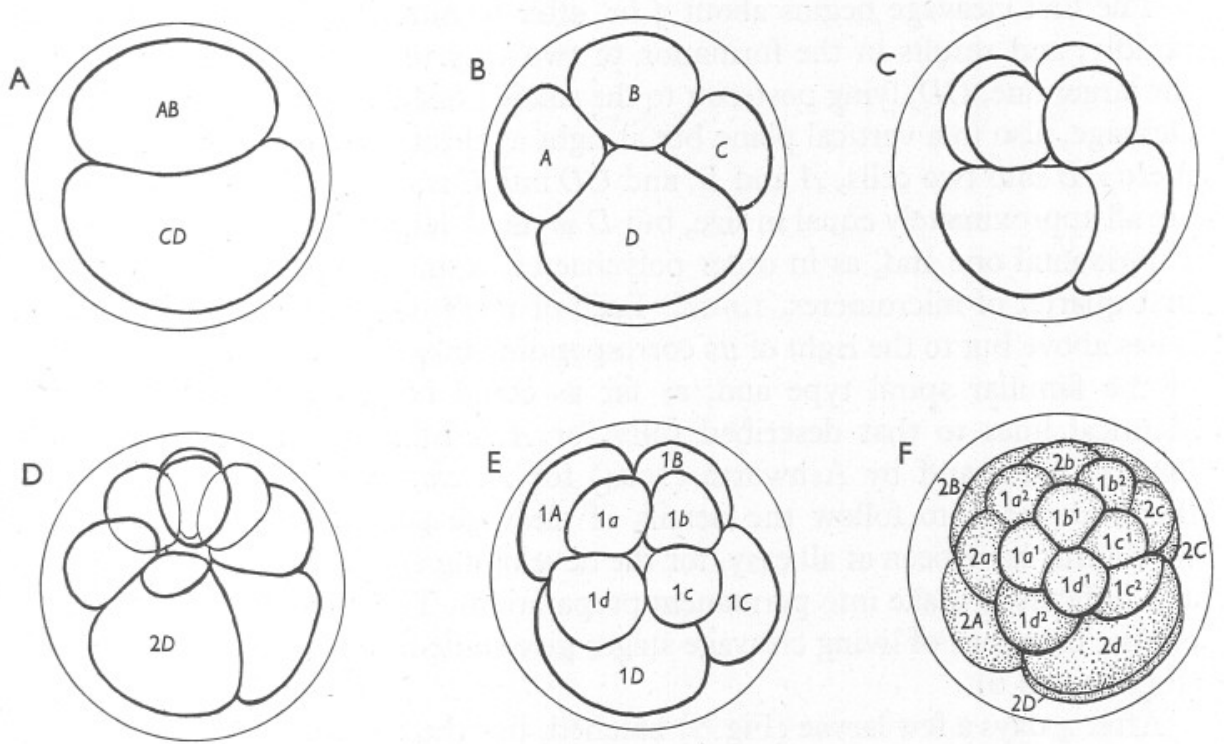

Fig. 5. Camera lucida drawings of cleavage stages. A, 2-cell stage. B, 4-cell stage from animal pole. C, 8-cell stage from the side. D, 2nd quartet of micromeres being formed. E, 8-cell stage from the animal pole. F, I6-cell stage from the animal pole.

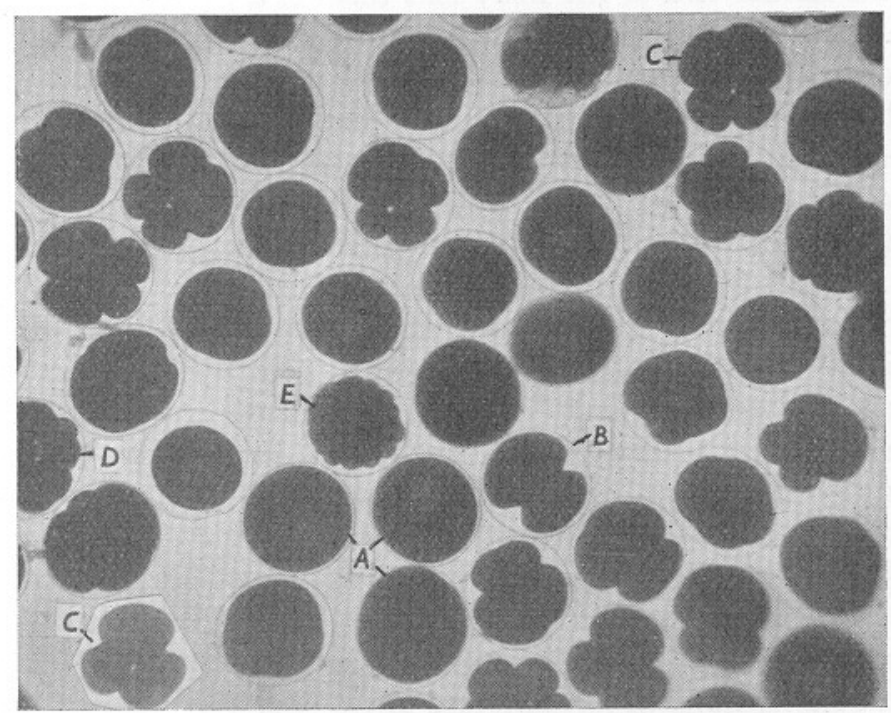

Fig. 6. Untouched photomicrograph of living cleavage stages. A, fertilized egg. B, 2-cell stage. C, 4-cell stage from the animal pole. D, I6-cell stage. E, blastula. 
The first cleavage begins about $3 \mathrm{hr}$. after fertilization, is completed fairly rapidly, and results in the formation of two very unequal-sized blastomeres, the larger one, $C D$, lying posterior to the smaller one, $A B$ (Fig. 5). The second cleavage, also in a vertical plane but at right angles to the first, divides blastomere $A B$ into two cells, $A$ and $B$, and $C D$ into $C$ and $D$. Of these $A, B$ and $C$ are all approximately equal in size, but $D$ is much larger. The third cleavage is a horizontal one and, as in other polychaetes, results in the formation of the first quartet of micromeres, $\mathrm{I} a-\mathrm{I} d$. Each of these is cut off obliquely so that it lies above but to the right of its corresponding megamere. Cleavage is, then, of the familiar spiral type and, as far as could be seen, it follows almost identical lines to that described fully for $A$. cristata by Child (I900) and Okada (I94I) and by Ashworth (1904) for A. claparedii. No attempt was therefore made to follow the details of cleavage and gastrulation. Neither would this have been at all easy, for the developing eggs are singularly opaque and difficult to make into permanent preparations. The photomicrographs and outline drawings of living cleavage stages give some idea of early development (Figs. 5 and 6).

After 4 days a few larvae (Fig. 7) hatched, but the rest of the embryos died, since it was difficult to maintain satisfactory conditions in the small aquarium which alone was available. The larvae, like the eggs, are very opaque and creamy pink in colour. They are about $0.24 \mathrm{~mm}$. long, and shaped rather like a radish. There is a well-defined prototroch encircling the thickest part of the body at about one-quarter of the way from the anterior end. A telotroch encircles the hinder end of the body and there is a prominent apical tuft of long cilia. Some distance behind the apical tuft, but on the dorsal side, is a pair of dark brown eye spots, whilst along the ventral surface, between the prototroch and the telotroch, is a band of shorter cilia. Neither mouth nor anus appears to be formed, but owing to the opacity of the larvae little could be seen of the internal structure, either in living larvae or in stained mounts. This is unfortunate, because only brief descriptions of early $A$. marina larvae are available. In fact, the only account that has been found is that of Blegvad (I923), who reared a few up to the time when three chaetigerous segments had differentiated. $\mathrm{He}$ also states that he found in September larvae with five chaetigerous segments, but gives no description of these nor does he mention where or how they were collected. Pirlot also found larvae with one chaetigerous segment in the sand, but neither describes nor figures them. Thorson (I946) mentions that E. Smidt has discovered early larvae, but again no description of them is given. He has, however, reasons for believing that from the first the larvae develop on the sand and remain there to develop further without ever becoming pelagic. Some confirmation of this view was found in the habits of the newly hatched larvae found in October 1947 for, unlike those of A. cristata (vide Lillie, 1905) or of A. claparedii (vide Ashworth, 1904), they often remained attached by their posterior end to the bottom of the dish and 


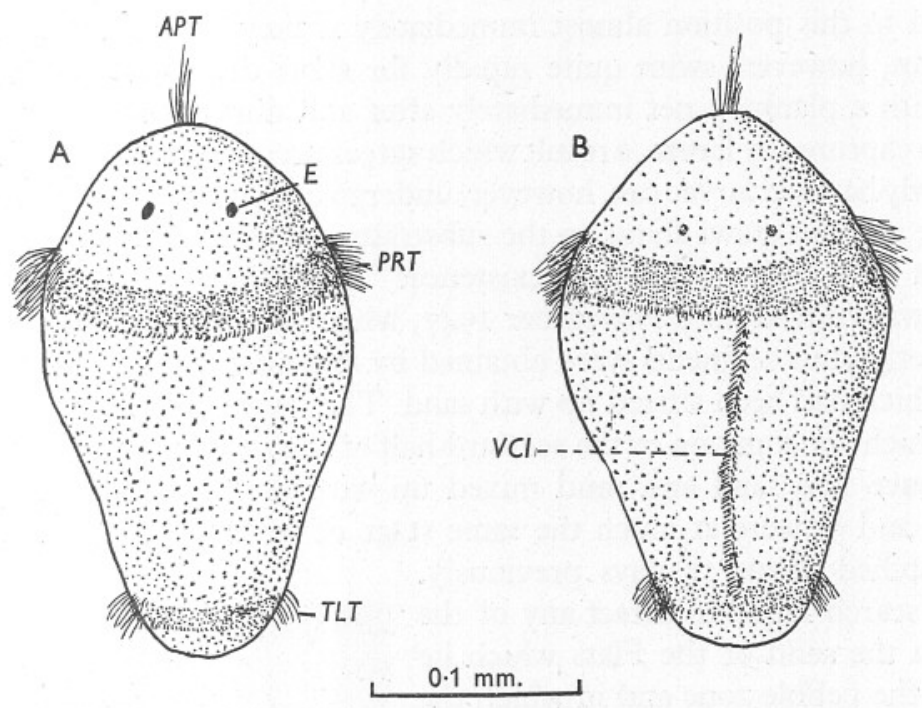

Fig. 7. Camera lucida drawings of newly hatched larvae. A, dorsal view. B, ventral view. $A P T$, apical tuft; $E$, eye; PRT, prototroch; $T L T$, telotroch; VCI, ventral ciliated band.
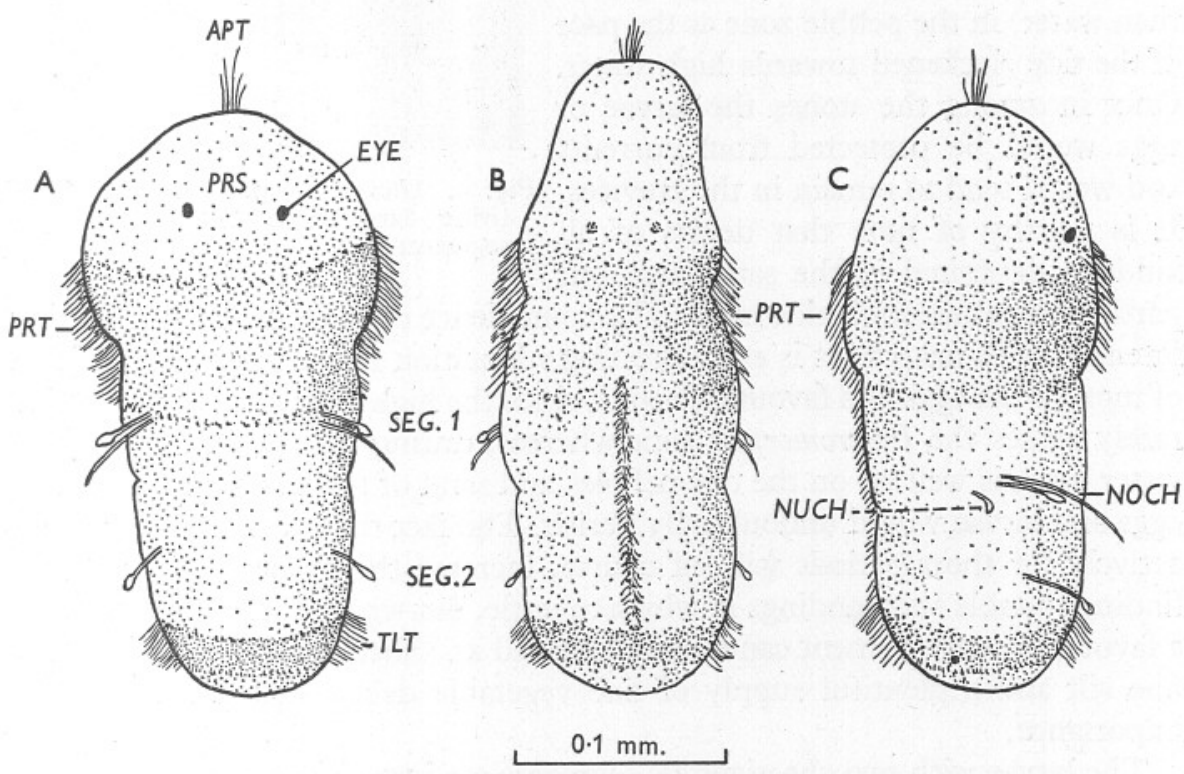

Fig. 8. Camera lucida drawings of living larvae with two chaetigerous segments taken from the Fucus zone. A, dorsal view. B, ventral view-prostomium extended. C, side view. $A P T$, apical tuft; $E Y E$, eye; $N O C H$, notopodial chaetae; $N U C H$, neuropodial chaetae; $P R S$, prostomium; PRT, prototroch; $S E G$, segment; $T L T$, telotroch. 
returned to this position almost immediately if they were forcibly detached. They can, however, swim quite rapidly for short distances. Also, repeated hauls with a plankton net immediately after and during the breeding season failed to capture any larvae, a result which agrees precisely with that of Thorson. The newly hatched larvae can, however, undergo considerable and rapid changes in shape and can crawl about on the substratum, seemingly well adapted from the first to a bottom-dwelling existence. That Thorson was undoubtedly correct was proved on 8 November 1947, when large numbers of larvae with two chaetigerous segments were obtained by straining through a plankton net water which had been stirred up with sand. They were taken from the shallow pools which are common in the seaward half of the pebble and Fucus zone and which have fine sand and mud mixed up with the shingle. All the larvae (Figs. 8 and 9) were at much the same stage of development and must have been hatched about I4 days previously.

Careful search failed to detect any of the larvae in the sand of the Flats which lie beyond the pebble zone and in which the spawning adult worms live, and it must be assumed that the fertilized eggs were carried towards the shore by the advancing tides and were deposited (being heavier than water) in the pebble zone as the pace of the tide slackened towards high water. Once in among the stones the larvae or eggs would be protected from currents and would tend to remain in the crevices. It is worthy of note that debris of all kinds is deposited in the same area but

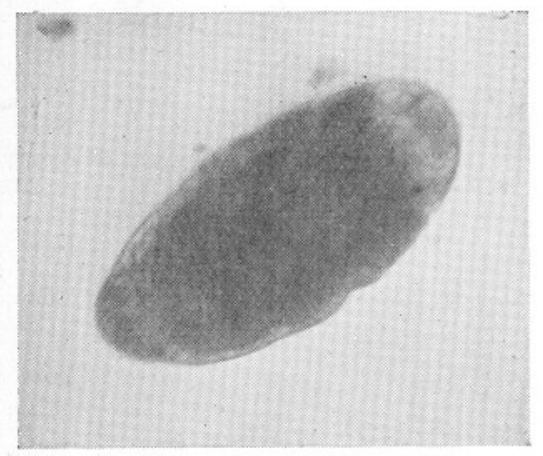

Fig. 9. Untouched photomicrograph of living larva with two chaetigerous segments. particularly at the high-tide mark. The coincidence of the maximum spawning intensity with neap tides is an interesting adaptation favouring the deposition of most of the eggs in a favourable zone, since the high-tide mark at these tides rarely passes the Enteromorpha zone whereas, during spring tides, the highwater mark is well up on the dry pebbles and sand of the beach proper where eggs and larvae would undoubtedly perish. The fact that the larvae can swim actively for short periods will, of course, increase the chances of the larvae finding suitable surroundings in which to settle, but what conditions constitute a favourable environment can only be guessed at. Shelter between the stones, fine silt and a plentiful supply of fine vegetable debris may perhaps be of importance.

The larvae with two chaetigerous segments are just visible to the naked eye as white specks about $0.25 \mathrm{~mm}$. in length, and at first glance much resemble a small planarian. When at rest the body is bluntly conical, the broader end being anterior. Here is borne the apical tuft, whilst a little distance behind on 
the dorsal side is a pair of dark brown eyes. Two rather indistinct grooves mark off the two segments. In the youngest of these larvae the anterior chaetigerous segment bears two notopodial chaetae, one of which is spoon-shaped and the other spear-shaped, but in some larvae this segment had also a single hooked neuropodial chaeta. The second chaetigerous segment bears a single chaeta only, which is spoon-shaped. Both prototroch, telotroch and ventral ciliated band are still present, but much wider, and it is by means of these that the larvae swim rapidly when detached from the bottom. Usually they crawl among the sand grains and detritus among which they live. They are extremely muscular little organisms, the prostomial region particularly being capable of a high degree of contraction and expansion. Reference to the descriptions of the larvae of Arenicola cristata given by Lillie (1905) and Okada (I94I) and of $A$. claparedii by Ashworth (1904) will show that the larvae of $A$. marina are very similar to those of $A$. cristata, but hatch at a slightly earlier stage, having at first no chaetae. They are in this respect more like those of $A$. claparedii, but develop more slowly.

Apparently nothing is known of the structure and mode of life of larvae intermediate between those with three chaetigerous segments and the postlarval stages of Benham (1893) which are occasionally taken in plankton hauls in the spring.

During this investigation evidence has been found for the view that the larvae remain throughout the winter in the top centimetre or two of the sand in or bordering the seaward edge of the Fucus zone. By the following spring they have metamorphosed and grown into small worms resembling the adults in all essential features. Certain it is that small worms about $\mathrm{I} \cdot 5 \mathrm{~cm}$. long are found for the first time each year in enormous numbers in this region and not elsewhere on the Flats.

There is every reason to be hopeful that some of the so-far missing intermediate larval stages will be found during the coming winter.

\section{Size Groups and Growth Rates}

The very extensive samples taken from the lugworm population at fairly regular intervals over the whole year November 1946 to November 1947 provided material which was used to gain some idea of the growth rates and of the age and size groups. For these purposes the length of the body, excluding the tail, of freshly dug worms was measured. This gave a more reliable index of size than does total length of the body, since the tail (posterior achaetous region of the body) varies greatly in its proportion to the rest of the body, being frequently shortened by damage and often almost absent. Lengths were measured only to the nearest $0.5 \mathrm{~cm}$., except on specimens of a year or less in age. The lengths refer to specimens in a moderate degree of contraction, a condition that they usually adopt a few seconds after being handled. The 


\section{TABle III. Average Length OF the Body} (EXCLUDING THE TAIL) IN CM.

$\begin{array}{lllllllllllll}\text { Young worms } & - & - & - & - & - & 0.8 & 1.5 & 2.0 & 2.4 & 3.75 & 4.3 & 4.0 \\ \begin{array}{l}\text { Total worm } \\ \text { population }\end{array} & 6.4 & 5.5 & 5.3 & 4.8 & 5.9 & 6.1 & 8.2 & 8.1 & 9.2 & 9.1 & 9.8 & 8.7\end{array}$

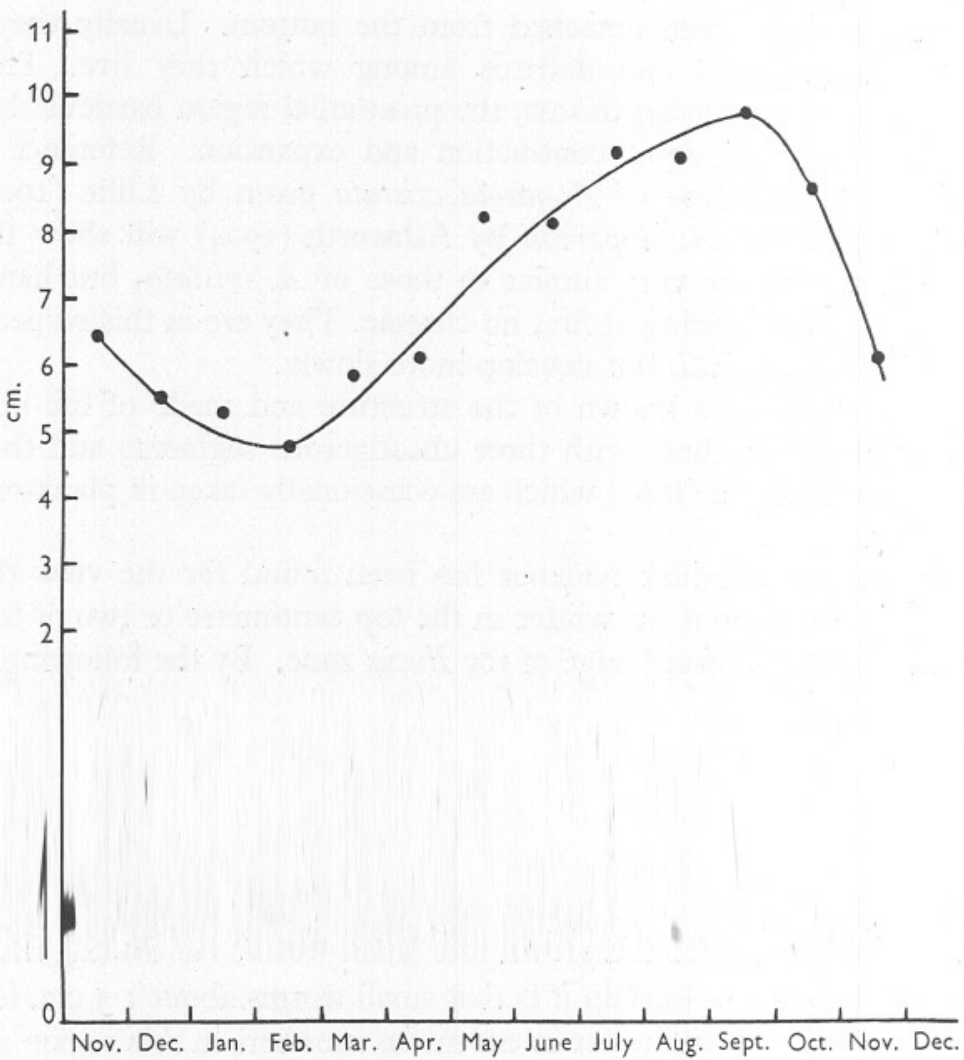

Fig. 10. Average length of body (excluding tail region) of adult worms.

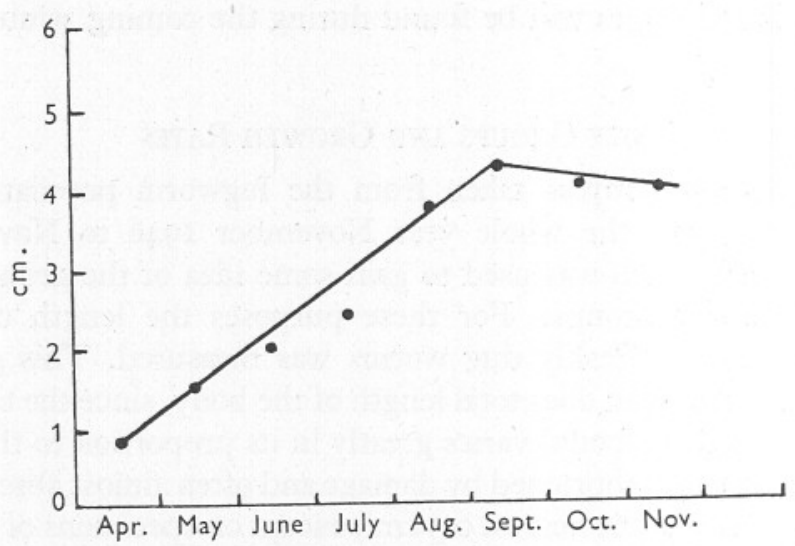

Fig. II. Growth curve of young worms as shown by average monthly length of body (excluding tail). 
results, although only approximate, gain in value from the very large number of worms which were measured.

The monthly figures for the average length of the body, excluding the tail, of all the worms collected are given in Table III and are expressed graphically in Fig. IO. Table III, also, and Fig. II show separately the average monthly lengths, excluding the tail, of young worms from eggs spawned in the autumn of I946. These worms are easily separable from all others by their small size, pinkish colour and, usually, by being found nearer the shingle beach.

\section{Table IV. Centimetre Size Groups in Worm Population} EXPRESSED AS OUT OF 200 WORMS

$\begin{array}{ccccccccccccc}\begin{array}{c}\text { Size } \\ \text { group } \\ \text { (cm.) }\end{array} & \text { Nov. } & \text { Dec. } & \text { Jan. } & \text { Feb. } & \text { Mar. } & \text { Apr. } & \text { May } & \text { June } & \text { July } & \text { Aug. } & \text { Sept. } & \text { Oct. } \\ 2-3 & - & - & 3 & 3 & \text { I } & \text { I } & - & - & - & - & - & - \\ 3-4 & 4 & 20 & 2 I & 26 & \text { II } & 7 & \text { I } & - & - & \text { I } & \text { I } & 2 \\ 4-5 & \text { I6 } & 25 & 40 & 43 & 3 I & \text { I5 } & \text { I } & 7 & \text { I } & 2 & 8 & 2 \\ 5-6 & 38 & 85 & 6 I & 73 & 62 & 33 & \text { I2 } & 2 \text { I } & 3 & 8 & 2 & 7 \\ 6-7 & 63 & 55 & 47 & 36 & 47 & 59 & 27 & 23 & \text { I2 } & \text { I4 } & \text { II } & 2 \text { I } \\ 7-8 & 58 & \text { I5 } & 29 & \text { I6 } & 3 I & 3 I & 48 & 48 & 37 & 24 & 20 & 43 \\ 8-9 & 20 & - & 5 & 3 & \text { II } & 23 & 39 & 46 & 38 & 35 & \text { I3 } & 4 \text { I } \\ 9-10 & - & - & 3 & - & 5 & \text { I5 } & 34 & \text { I9 } & 38 & 33 & 22 & 21 \\ \text { IO-II } & - & - & - & - & \text { I } & 7 & \text { I } & \text { I8 } & \text { I6 } & 30 & 45 & 24 \\ \text { II-I2 } & - & - & - & - & - & 4 & \text { I2 } & 7 & 20 & 23 & 28 & 2 \text { I } \\ \text { I2-I3 } & - & - & - & - & - & 3 & 5 & 5 & \text { I9 } & \text { I2 } & 20 & \text { I3 } \\ \text { I3-I4 } & - & - & - & - & - & - & \text { I } & 3 & 7 & \text { I4 } & \text { II } & 5 \\ \text { I4-I5 } & - & - & - & - & - & - & \text { I } & - & 7 & 3 & 8 & 3 \\ \text { I5-I6 } & - & - & - & - & - & - & - & 2 & \text { I } & \text { I } & - & -\end{array}$

The same figures were used to construct histograms (Table IV and Fig. I2) which show for each month the numbers of worms (to the nearest whole number) in a series of size groups which differ from one another by $\mathrm{I} \mathrm{cm}$. in length of the body, excluding the tail. Since the actual size of the samples was rather variable, the figures have been expressed as numbers out of 200 . It should be mentioned that these figures all refer to worms obtained from the same general area of the Flats about 50 yd. seaward of the pebble and Fucus zone. They do not, until April, include any of the 1946 brood of worms and even after this time young worms are exceedingly rare in this area until November, and so are lacking from some monthly samples.

\section{Discussion of Results}

From Table III and Fig. Io it will be seen that the average length of the worms decreases from about $6.4 \mathrm{~cm}$. in November to $4.8 \mathrm{~cm}$. in February, and then rises steadily to reach a maximum in September when the length index is $9.8 \mathrm{~cm}$. This is followed by a fairly sharp decrease in October and November 1947 until the average length index is only $6 \cdot 2 \mathrm{~cm}$. Young worms, from eggs spawned in the previous autumn, grow from $0.8 \mathrm{~cm}$. in April to $4.3 \mathrm{~cm}$. in September and then decrease to a length index of about $4.0 \mathrm{~cm}$., which probably remains fairly constant throughout the winter. By the 


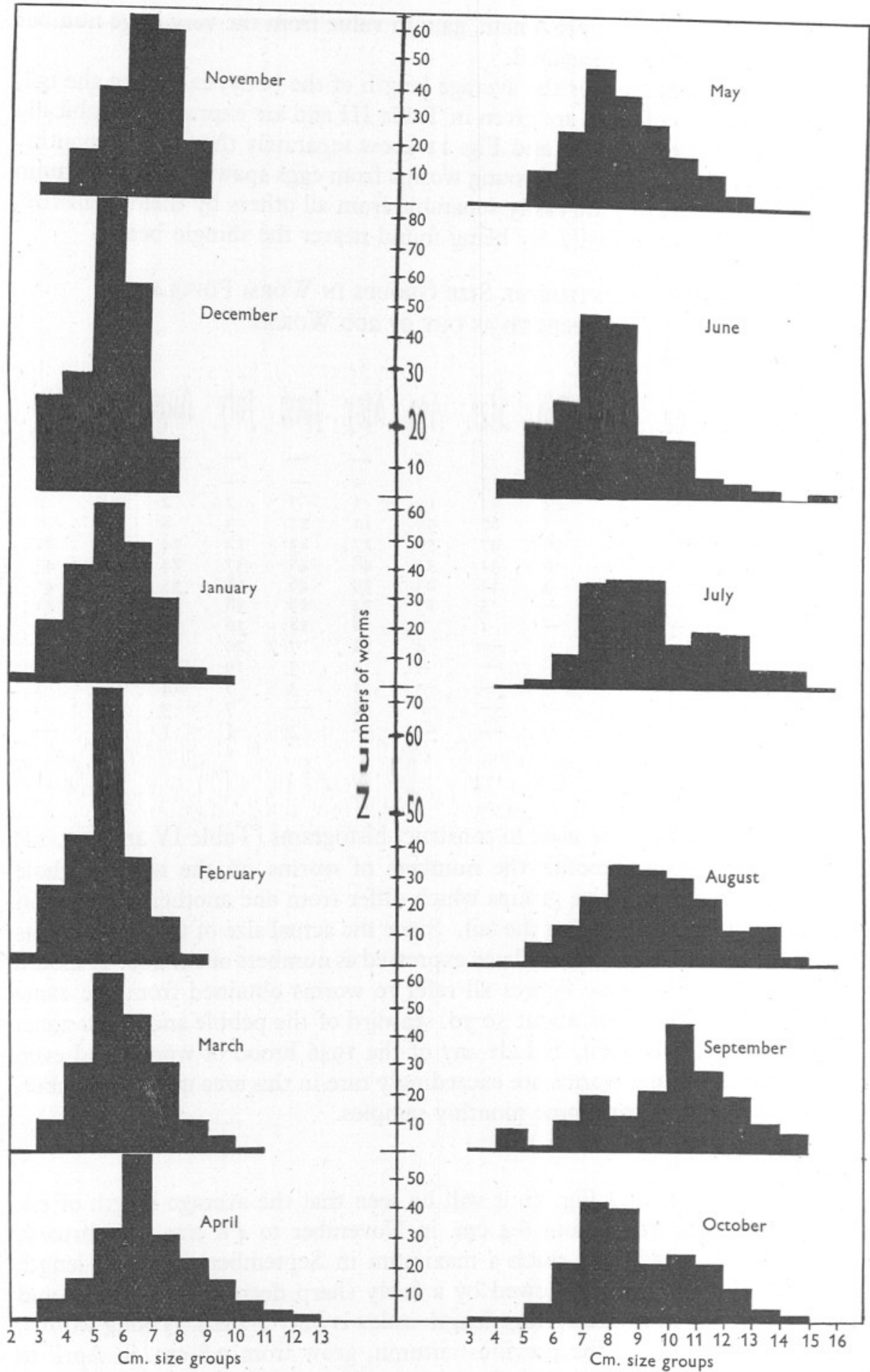

Fig. I2. Histograms showing numbers of worms in size groups differing by $\mathrm{I} \mathrm{cm}$. in length, November 1946 to October 1947. 
following spring (April and May) the young worms which had attained a length index of $4 \mathrm{~cm}$. in the previous September will have grown to a size which lies within the range of the adult size groups. Reference to Table I shows that in the autumn $98 \%$ of the worms contain ripe germ cells so that it is clear that worms become sexually mature in their second summer and spawn 2 years after hatching from the egg. They can certainly spawn more than once, but how many times in not certain.

The histograms show a gradual change in the proportion of the various size groups. During the winter from December to March the $5-6 \mathrm{~cm}$. group is the largest; in April it is the $6-7 \mathrm{~cm}$.; in May the $7-8 \mathrm{~cm}$. group is the largest; whilst in June the $7-8$ and $8-9 \mathrm{~cm}$. groups are about equal in size. By July the 7-IO $\mathrm{cm}$. groups predominate and the $8-\mathrm{II} \mathrm{cm}$. in August. In September the IO-II cm. group is the largest, but after October even worms exceeding $9 \mathrm{~cm}$. in length are rare, whereas from May to October worms with a length index of up to $16 \mathrm{~cm}$. are found. Now it has already been mentioned (p. 564) that at the end of October and during the first week of November there is evidence of a mortality of about $40 \%$ of the adult worms. From the histograms it looks extremely probable that the worms which die are those in the larger size groups, that is, of $10 \mathrm{~cm}$. and above. These presumably would be those which had reached a maximum size and had spawned for the last time. It will be seen that the size groups of $\mathrm{IO} \mathrm{cm}$. and upwards for October represent about $37 \%$ of the total-a figure which agrees well with the loss of $40 \%$ estimated by another method.

This explanation is, however, inadequate to account completely for the decrease in size of the worms during the late autumn and winter. It can be seen that whilst the young (I946) worms grew steadily until September, yet from this time onwards they show a slight decrease in size. The same is true for the older worms as is shown by the decrease in average length from November to February. It seems that there is a period of 'degrowth' possibly due to the exhaustion of spawning and perhaps also because food is scarce at this time of the year. In this connexion I am indebted to Mr Wells for drawing my attention to the fact that lugworms kept in sea water alone remain alive and in good condition for long periods but become gradually smaller.

\section{MigRations}

Often regarded as an extremely sluggish animal, the lugworm is more active than is commonly supposed. It was repeatedly noticed that at all seasons of the year areas of soil from which all, or practically all, the worms had been removed by digging had been repopulated in the course of a few days to a normal density. It is possible that this repopulation was brought about by worms burrowing through the soil, but there is some evidence that worms leave their burrows when they are covered by the tide and swim to new situations and make fresh burrows. It has been noted that they can disappear into 
the soil quite rapidly, in fact, in about 3-4 min. (Chapman \& Newell, I947). On many occasions worms have been seen swimming in the aquarium, whilst reports of this occurring in nature have already been mentioned (p. 556). It may be suggested that worms captured when free-swimming are in fact merely migrating to new burrows, and that this may take place quite independently of spawning or the season of the year. Thus Meek \& Storrow (1924) found swimming lugworms in March, and yet Storrow (1925) brought forward strong evidence that the breeding season was in September.

A simple experiment carried out in the autumn of 1947 provides yet further evidence that the worms can and do swim under natural conditions. A bucket was filled with soil and partially buried in the Flats so that a few inches of its rim projected above the surface. Some weeks later it contained an active adult worm which must have come in over the top of the bucket and could have done so only by swimming when the tide was up since lugworms seem unable to crawl on the surface.

The occurrence of post-larval stages in the spring plankton would then perhaps be best explained neither as accidental (Thorson, 1946) nor as the end product of a very extended pelagic larval phase (Blegvad, I923; Thamdrup, I935), but as short migrations to places suitable for the continuation of the adult mode of life.

Whatever may be the normal method by which lugworms change the location of their burrows, it seems that this is a normal and often repeated process, and is responsible for the distribution of the animals throughout the habitat. It is, perhaps, of particular importance to the worms of less than a year old. These are first detectable in the spring (April in 1947) by the enormous numbers of minute castings along the shoreward edge of the Fucus zone where there may be as many as 250 per sq. yd. Here the small worms grow rapidly and then gradually migrate away from the shore to mingle with worms spawned in previous years.

\section{SUMMARY}

The breeding season of the lugworms of the Whitstable area is a sharply defined one, extending for I4 days between the new moon and full moon spring tides in the second half of October. Spawning begins slowly and reaches a maximum at the intervening neap tides and then declines in intensity.

Both eggs and sperms are discharged from the burrows at extreme low water to lie on the surface of the sand. Here fertilization occurs.

No germ cells were detected in the body cavity from November to June, but from August oniwards to the end of October $98 \%$ of the adult worms are ripe.

At the end of the spawning period about $40 \%$ of the adults die.

A brief description of gametogenesis and of the mature gametes is given.

Germ cells are discharged through the nephridia. 
There is a differential sex ratio of 3.75 females to I male.

Coelomic gametes cannot be used for a completely successful artificial insemination, the eggs always dying after undergoing a few cleavages.

Fertilization and cleavage are briefly described. The eggs are fertilized as primary oocytes and undergo spiral cleavage in the way described by Child and others for different species of Arenicola.

Four to five days after fertilization the larva hatches. It is a very opaque trochophore $0.24 \mathrm{~mm}$. long and usually rests sticking to the substratum, although it can swim actively. It has a broad prototroch, a telotroch and a mid-ventral tract of shorter cilia. There is an apical tuft and a pair of dark brown eyes. Mouth and anus do not seem to be open at this stage.

Larvae of about I4 days old and $0.25 \mathrm{~mm}$. in length, and having two chaetigerous segments, are described. They were abundant in the silt between the pebbles of the Fucus zone, but no larvae were taken in the plankton nor in the sand of the Flats in which the adults spawned. It is suggested that fertilized eggs and larvae are carried inshore by the tide and are deposited in the Fucus zone where they live and develop into small worms in the winter and early spring of the following year. There is no extended pelagic larval phase, the modified trochophore larvae being demersal from the first.

Tables and graphs showing the growth of the young worms are given. The length of the body, excluding the tail, is taken as giving a true index of total length. The young worms hatched in 1946 were first noticed in April I947 and by September had attained a length index of $4.3 \mathrm{~cm}$.

The average length of the body, excluding the tail, for adults is also given in tabular and graphic form. This reaches its maximum $(9.8 \mathrm{~cm}$.) in September, but declines rapidly at the end of October and early November to the low level of about 5 or $6 \mathrm{~cm}$. through the winter to rise again in the following spring.

From the histograms showing the numbers of worms in size groups differing by $\mathrm{I} \mathrm{cm}$. in length it is concluded that the sudden decrease in average length of the adult population at the end of October and early November is due to a mortality of adult worms (already mentioned) which have spawned for the last time. Worms spawn for the first time when they are 2 years old.

Further decrease in average length during the winter is due to other causes and affects the young as well as the adult worms.

Evidence is brought forward for the view that lugworms sometimes leave their burrows and swim for short distances probably to seek situations for new burrows. This kind of migration may be responsible for dispersing the animals throughout the habitat and accounts for its repopulation by young worms from the edge of the Fucus zone. 


\section{REFERENCES}

Ashworth, J. H., I904. Arenicola. L.M.B.C. Memoir, No. xI. Liverpool.

Benham, W. B., I893. Post-larval stage of Arenicola marina. Fourn. Mar. Biol. Assoc., Vol. III, pp. 48-53.

Blegvad, H., I923. Preliminary note on the eggs and larvae of Arenicola marina L. Vidensk. Medd. Dansk. Nat. For. København, Bd. 76, pp. I-3.

Bohn, G., I903. Observations biologiques sur les Arénicoles. Bull. Mus. Hist. Nat. Paris, Vol. Ix, pp. 62-73.

Chapman, G. \& Newell, G. E., I947. The rôle of the body fluid in relation to movement in soft-bodied invertebrates. I. The burrowing of Arenicola. Proc. Roy. Soc. B, Vol. I34, No. 877 , pp. 43 I-55.

CHILD, C. M., I897. A preliminary account of the cleavage of Arenicola cristata, with remarks on the mosaic theory. Zool. Bull., Vol. I, pp. 7I-86.

- 1898. The maturation and fertilisation of the egg of Arenicola marina. Trans. New York Acad. Sci., Vol. xvi, pp. 387-94.

- I 1900. The early development of Arenicola and Sternaspis. Arch. Entwick., Bd. 9, Heft 5, pp. 587-723.

Cunningham, J. T. \& Ramage, G. A., I888. The Polychaeta Sedentaria of the Firth of Forth. Trans. Roy. Soc. Edin., Vol. xxxiII, pp. 635-84.

FAGE, L. \& LegendRE, R., 1927. Pêches planctoniques à la lumière effectuées à Banyuls-sur-Mer et à Concarneau. I. Annélides polychètes. Arch. Zool. Exp. et Gén., T. 67, pp. 23-222.

Gamble, F. W. \& Ashworth, J. H., I900. The anatomy and classification of the Arenicolidae, with some observations on their post-larval stages. Quart. F. Micr. Sci., Vol. 43, pp. 419-569.

HentSCHel, .C. C., I930. On the correlation of the life-history of the acephaline gregarine, Gonospora, with the sexual cycle of its host. II. Gonospora (Kalpidorhyncus) arenicolae. Parasitology, Vol. xxII, pp. 505-9.

KYLE, H. M., I896. On the nephridia, reproductive organs, and post-larval stages of Arenicola. Ann. Mag. Nat. Hist., Vol. xvIII, pp. 295-300.

LILlIE, R. S., I905. The structure and development of the nephridia of Arenicola cristata Stimpson. Mitt. Zool. Stat. Neapel, Bd. I7, pp. 34I-405.

MeEK, A. \& Storrow, B., I924. On a pelagic phase of Arenicola marina and of Eteone arctica. Ann. Mag. Nat. Hist., Vol. xIv, pp. 453-55.

OKaDA, K., I94I. Gametogenesis, breeding habits and early development of Arenicola cristata Stimpson, a tubicolous Polychaete. Sci. Rep. Tôhoku Imperial Univ., 4th ser. Biol., Vol. xvi, No. 2.

Pirlot, J. M., I933. La ponte de l'Arenicola marina Linné à la côte Belge. Bull. Mus. Roy. Hist. Nat. Belg., T. Ix, No. 49, pp. I-7.

Storrow, B., I925. Faunistic notes. Rep. Dove Marine Lab. Cullercoats for I925, Vol. I4, p. 57.

Thamdrup, H. M., I935. Beiträge zur Ökologie der Wattenfauna auf experimenteller Grundlage. Medd. Komm. Danmarks Fisk. Havund., Kobenhavn, Ser. Fisk., Bd. x, No. 2, I25 pp.

Thorson, G., I946. Reproduction and larval development of Danish marine invertebrates, with special reference to the planktonic larvae in the Sound (Ø̈resund). Medd. Komm. Danmarks Fisk. Havund., Kobenhavn, Ser. Plankton, Bd. 4, No. I, $523 \mathrm{pp}$.

Wells, G. P., I945. The mode of life of Arenicola marina L. Fourn. Mar. Biol. Assoc., Vol. XXvi, pp. 170-207.

Williamson, H. C., I9r6. The spawning and exuviation of Arenicola. Fourn. Zool. Res., London, Vol. I, pp. I02-II. 